\title{
A Comparison of Electronic Design and Analysis Packages
}

\author{
Elaine Cooney, Carlos Monsanto \\ Indiana University Purdue University Indianapolis
}

Introduction

There have been great strides in Electronic Design and Analysis (EDA) packages in the past few years, both in capabilities and "user-friendliness". This paper examines four EDA packages: Electronics Workbench Version 5, MicroSim Design Lab Version 8, Orcad Release 9, and Protel 98. (These were the software versions available while this research was being conducted. The authors recognize that by the time this paper is published, some, if not all, of the versions discussed will be superseded.) This comparison uses the student or demonstration versions which are available for each of these packages.

Although many criteria may be used to evaluate software, the focus of this project is finding the right software package for undergraduate use. Criteria include: availability of documentation; overall ease of use; ease of schematic entry, including ability to customize display; amount and relevancy of devices available; ability to edit and create devices; total size of circuitry allowed; simulation capabilities; and ability to simulate a variety of circuits accurately.

To perform this comparison, the same circuit schematics were entered into each of the packages and simulated. A variety of analog and digital circuits were used. The experiences and results were then compared using the above criteria. In addition, students were surveyed about their experiences with EDA software.

\section{EDA Packages}

Electronics Workbench ${ }^{1}$ Student Version (EWB) has been aggressively marketed to education, both on the post-secondary and even high-school level. The student addition, available for less than $\$ 100$ from the company's website, was reviewed here, but the company also sells a professional version (at a much higher price). The most obvious difference between the professional and student edition seems to be the number and variety of part libraries. The user interface models a lab setting - the user virtually wires together components, power supplies, a function generator, meters and oscilloscope and observes a simulation of how this equipment works together. It can be used as practice lab experience. PCB layout is available as an add-on package (at an additional charge). Electronics Workbench is presented in first-semester freshman electrical engineering technology courses at IUPUI.

MicroSim Design Lab Version 8 Evaluation Version (MicroSim) was originally produced as a demonstration: engineers would use it to "test drive" the product before placing an order for the actual software. MicroSim also generously allowed educators and students to download the evaluation version or receive promotional CDs at no charge and encouraged the software's use 
in educational settings by cooperating with authors of textbooks and offering substantial educational discounts on the professional version. In one interface it provided schematic capture, simulation, and PCB layout. MicroSim was purchased by Orcad and Design Lab is no longer for sale. However, Orcad continues to allow students to download Version 8 from its website. At IUPUI, MicroSim introduced in introductory electrical engineering courses and sophomore level electrical engineering technology courses.

Orcad Release $9^{2}$ (Orcad) also provides schematic capture, simulation and PCB layout, but the professional versions of each of these capabilities must be purchased separately. The demonstration software evaluated here includes all of these capabilities, with limitations in parts count and schematic size, but is not available for download. Orcad will send a CD to students or educators who request a copy through their website. Strong criticism of this package compared to Design Lab, especially in its schematic capture interface, has been expressed by both educators ${ }^{3}$ and EDA professionals ${ }^{4}$.

Protel $98^{5}$ (Protel) is an alternative to Orcad offered by an Australian firm. Like Orcad, capabilities for schematic capture, simulation, and PCB layout must be purchased separately, but are all available in a demonstration version. This demo version offers an extensive parts list and other capabilities, but is only good for 30 days and may not be re-installed on the same hard drive.

\section{Student Survey}

After identifying the four software packages to be compared, the first part of this research involved surveying 67 students at IUPUI. These students included freshmen through seniors enrolled in EET and EE courses. The list of questions posed and summarized results are in Table 1.

All but one of the respondents had used either Electronics Workbench or MicroSim Design Lab. Twenty-five had used both packages. None of the students had used either of Orcad or Protel, so the student data available is only for EWB and MicroSim.

\begin{tabular}{|c|c|c|}
\hline $\begin{array}{l}\text { Have you used any of the following } \\
\text { software? If more than one, indicate the } \\
\text { order you've learned the software. }\end{array}$ & EWB & MicroSim \\
\hline $\begin{array}{l}\text { How long did it take you to become } \\
\text { comfortable with the software? } \\
\text { 1. One lab period; } 2 \text {. Two weeks; } \\
\text { 3. Eight weeks; } 4 \text {. the entire semester }\end{array}$ & 1.9 & 2.5 \\
\hline $\begin{array}{l}\text { Rate the difficulty of use for analog circuits } \\
\text { Easy } 12345 \text { Difficult }\end{array}$ & 2.2 & 2.6 \\
\hline $\begin{array}{l}\text { Rate the difficulty of use for digital circuits } \\
\text { Easy } 12345 \text { Difficult }\end{array}$ & 1.9 & 2.7 \\
\hline $\begin{array}{l}\text { How successful were you at starting the } \\
\text { software? } \\
\text { Very successful } 12345 \text { Not successful }\end{array}$ & 1.6 & 1.7 \\
\hline $\begin{array}{l}\text { How successful were you at entering the } \\
\text { first schematic? } \\
\text { Very successful } 12345 \text { Not successful }\end{array}$ & 2.0 & 2.2 \\
\hline $\begin{array}{l}\text { How successful were you in simulating the } \\
\text { circuit? } \\
\text { Very successful } 12345 \text { Not successful }\end{array}$ & 1.8 & 2.5 \\
\hline $\begin{array}{l}\text { How successful were you in displaying the } \\
\text { results? } \\
\text { Very successful } 12345 \text { Not successful }\end{array}$ & 2.2 & 2.5 \\
\hline $\begin{array}{l}\text { How successful were you printing your } \\
\text { results? } \\
\text { Very successful } 12345 \text { Not successful }\end{array}$ & 1.9 & 2.0 \\
\hline $\begin{array}{l}\text { Were you able to find everything you } \\
\text { needed in the online "help"? Yes } 1 \text { No } 0\end{array}$ & 0.46 & 0.88 \\
\hline $\begin{array}{l}\text { Were there any feature missing you would } \\
\text { like this software to have? }\end{array}$ & & \\
\hline $\begin{array}{l}\text { What do you look for in a good piece of } \\
\text { software? }\end{array}$ & & \\
\hline
\end{tabular}

Table 1: Student Survey Results 
Fifty-seven of the students responding had used EWB. On average, it took students two weeks to become comfortable with the software and they found all phases of its use moderately easy. Student response to the online help was mixed, with approximately half of the students who tried to use it finding the information that they were looking for. When asked about missing features, students most often listed the need for more explanation of procedures and more components.

Thirty-four students had used MicroSim. Compared to EWB, students found it took slightly longer to become comfortable (approximately one month) and they found tasks moderately easy to average to perform. They were more successful finding needed information in the help files than in EWB. Students listed the features they found missing to be adequate part availability and more explanation of circuit errors.

Unfortunately, not many of the students who had used both packages indicated the order they had learned the software, so direct comparisons between packages are difficult to make with this data. One student who had used both expressed a preference for MicroSim.

Some of the features students desired in software packages include "user friendliness", good help files, price, adequate component selection, and simulation capabilities. One freshman student summarized it well when s/he replied that a good piece of software is "user friendly but advanced enough to be useful."

\section{Results of Software Testing}

Each author evaluated each piece of software by attempting to enter and simulate a variety of schematics. Circuits included combinational logic, sequential logic, and an analog amplitude modulation circuit using discrete components. Time did not permit evaluation of PCB layout software.

Of all the packages tested, Electronics Workbench had the most intuitive interface. All the schematics were successfully captured. Access to parts lists was easy, and there were many components to chose from. Simulation was successful and results for transient, frequency, Fourier, noise, and distortion analyses could all be displayed. The biggest draw back was that the simulation could only display node voltages, and not current, gains, input impedance or output impedance.

Both authors had previous experience with MicroSim. Schematic capture and simulation went smoothly. Steps included selecting components from a single list formed from all the libraries loaded, setting component values, wiring components, selecting simulation options, and simulating. Some helpful features included:

- The ability to turn "rubber banding" on and off to facilitate the movement of parts

- $\quad$ Changing the display of part names and values by simply double clicking on the component and changing the default. Also, these labels could be moved around the part for optimal viewing.

- $\quad$ Operating point voltages and currents could be displayed on the schematic. This option could also be turned off. 
- Voltage and current markers in the schematic set default variables for display in Probe, the graphical display program which was used to present the results of simulation.

Additional voltages, currents, and mathematical combinations (including $\mathrm{dB}$ ) were also available.

Most of the parts need for the designs were included in the evaluation version. The parts list did not, however, have a seven-segment display, which was required for the sequential logic circuit. This circuit had to be designed in the same manner as a prototype construction with a 74LS47 $\mathrm{BCD} /$ Decoder. Although parts could be created and added to a library, the evaluation version had a limit on the number of parts that could be accessed, and the size and parts count that could be included.

The first step in an Orcad design was to load the libraries of choice (analog, digital etc.) The demonstration version had a limit of 15 parts per library and would not save a design with more than 30 components. The component parts list was divided into three dialog boxes or pull down menus: components, place grounding, and place power. Some of the digital parts were not available in the library. However, these components were available for download. Schematic capturing was successful, although the learning curve was steeper than the previous packages. The authors had great difficulty determining how to simulate the captured schematics. The instructions indicated that the design had to be captured in the "physical mode" and some optional features (using capture with simulate, inter-tool communications, etc.) had to be enabled. There were many steps required for simulating even a simple circuit. The authors still were not successful in simulating any of the three schematics after setting the parameters. The software had many of features and capabilities, but the user needed fairly extensive knowledge of the software features in order to be successful in starting, entering schematic, and displaying results.

Protel also required that libraries be loaded in order to start a design. The parts selection was huge. The schematic capture process was not intuitive, and took a great deal of time. Although there were many features, several (such as bill of material management) were not needed for undergraduate use and only complicated the learning process. A severe limitation was the limited number of sources available: $\pm 5 \mathrm{Vdc}, \pm 12 \mathrm{Vdc}, 1 \mathrm{kHz}-, 10 \mathrm{kHz}-, 100 \mathrm{kHz}-, 1 \mathrm{MHz}$ sine waves and $1 \mathrm{kHz}-1 \mathrm{MHz}$ pulses. Looking for the right component took a great deal of time because the library had to be specified. The authors were unsuccessful simulating any of the circuits because of lack of sources or inability to locate parts. This software had some great features, but they were too complicated to work with.

A summary of the software evaluation findings is presented in table 2 .

\section{Conclusions}

Electronics Workbench Version 5 Student Edition performed very well as an introductory schematic capture and simulation package. Students found it moderately easy to use, and the authors agreed that minimal instruction time would be needed for undergraduate students. The "lab bench" interface could be effectively used to simulate what would happen in the laboratory, 


\begin{tabular}{|c|c|c|c|c|}
\hline & MicroSim & EWB & Orcad & Protel \\
\hline \multicolumn{5}{|l|}{ Availability of documentation } \\
\hline Overall ease of use & Good & Good & $\overline{\mathrm{OK}}$ & Fair \\
\hline Ease of schematic entry & Very Good & Good & Fair & Fair \\
\hline $\begin{array}{l}\text { Amount of devices available for } \\
\text { installation }\end{array}$ & Very Good & $\begin{array}{l}\text { Additional } \\
\text { libraries } \\
\text { available for } \\
\text { purchase }\end{array}$ & Excellent & Excellent \\
\hline $\begin{array}{l}\text { Amount of devices available for } \\
\text { immediate use }\end{array}$ & OK & Good & OK & $\begin{array}{l}\text { Excellent, but } \\
\text { difficult to locate } \\
\text { specific parts }\end{array}$ \\
\hline Ability to edit and create devices & OK & $\begin{array}{l}\text { None } \\
\text { documented }\end{array}$ & Poor & Fair \\
\hline Total size of circuitry allowed & 50 parts & ? & 30 parts & $?$ \\
\hline Simulation capabilities & Excellent & Fair & Unsuccessful & Unsuccessful \\
\hline $\begin{array}{l}\text { Ability to simulate a variety of } \\
\text { circuits accurately }\end{array}$ & Excellent & Good & Unsuccessful & Unsuccessful \\
\hline
\end{tabular}

and students could quickly observe a limited number of dc currents and voltages and ac voltages. Perhaps its' greatest strength was in the ability to deal with combinational logic: it could except input from K-maps, Boolean expressions, or schematics, and a variety of digital displays were available. Its' weaknesses lay in the lack of ability to fully take advantage of the SPICE simulation. No ac currents were available for display. The ac and transient voltage information could only be graphed at indicated nodes and could not be manipulated in anyway. This prevented the plotting of impedances, voltage gains, and power measurements that are often the desired outputs of circuit simulations.

MicroSim Design Lab Evaluation Version 8 proved to be a more powerful simulation package, though slightly less user-friendly. Only dc currents and voltages could be displayed on the schematic, but an extensive selection of transient and frequency data was available in the plotting program Probe. It was well suited to undergraduate use at all levels. This demonstration version would sufficient for the majority of undergraduate assignments, but would not allow enough parts for extensive term projects. This could have been overcome if institutions could purchase a few copies of the professional version, but it was no longer available. Support for this program was limited if not non-existent.

Orcad Release 8 was far less user friendly. It would require far more instruction time on the software package, taking away from time spent on circuit theory and practice. In addition, the demonstration version had such severe limitations on availability and parts count as to make it inappropriate for any substantial part of an undergraduate program.

Like Orcad, Protel 98 demonstration version was not a viable solution for undergraduate use. Even if the software was more intuitive, the 30-day, one time installation would make it impractical for a semester's worth of work, let alone an entire program's. 
In conclusion, the authors find that EWB is a good introductory EDA package, but MicroSim may be a better choice for more advanced work. There cannot be one EDA package that will meet everyone's needs, but these results may help EE and EET programs select the package that is right for specific learning objectives.

Bibliography

1. Interactive Image Technologies. Electronics Workbench. URL: http://www.interactiv.com/index.html (12/4/99).

2. Orcad, Inc. Orcad electronic design automation (eda) software tools and services for engineers. URL: http://www.Orcad.com (12/4/99).

3. Fleeman, S. (July, 1999). The New PSpice Recipe Makes Most Educators Glad They Already 8. URL: http:/ednet.rvc.cc.il.us/ SteveF/psipce.htm (12/4/99).

4. Various. (11/16/1999-11/21/1999). Can anyone say anything good about OrCAD Capture? Forum: sci.electronics.cad (12/6/1999).

5. Protel International Limited. (1996-1999). Protel International - Making Electronic Design Easy. URL: http://www.protel.com (12/4/99).

\section{ELAINE M. COONEY}

Elaine Cooney is an Associate Professor of Electrical Engineering Technology in the Purdue School of Engineering and Technology at Indiana University Purdue University Indianapolis. She received her Bachelors of Electrical Engineering from GMI Engineering and Management Institute and her Masters of Electrical Engineering from Purdue University. Her areas of interest include analog circuits and electronics manufacturing.

\section{CARLOS R. MONSANTO}

Carlos Monsanto is a junior studying Electrical Engineering Technology at Indiana University Purdue University Indianapolis. Before coming to IUPUI, he worked at the "Bureau Telecommunicantie" Sint Maarten, Netherlands Antilles. His areas of interests included analog devices, digital circuits, communications, and computer networks. 